Joanna M. Karolczak

\title{
Ocena możliwości łączenia mandatu posła z funkcją inkasenta podatkowego ${ }^{1}$
}

\author{
Assessment of the possibility of combining a Deputy's mandate \\ with the function of a tax collector
}

\begin{abstract}
In the opinion of the author, the occupation and income resulting from the function of a tax collector should be indicated in the Register of Benefits and the statement regarding the financial status. If the village administrator collected taxes as a part of his business activity, he would have to cease from performing such activity. An additional occupation in the form of tax collection by a village administrator does not affect the Deputy's salary.
\end{abstract}

Keywords: incompatibility of a mandate, Deputy, soltys [rural administrative unit leader]

\begin{abstract}
Zdaniem autorki opinii zajęcie i dochody wynikające z funkcji inkasenta podatków powinny być wykazane w Rejestrze Korzyści oraz oświadczeniu majątkowym. Gdyby sołtys pobierał podatki w ramach prowadzonej przez siebie działalności gospodarczej, musiałby zaprzestać takiej działalności. Zajęcie dodatkowe w postaci pobierania podatków przez posła sołtysa nie ma wpływu na uposażenia poselskie.
\end{abstract}

Słowa kluczowe: niepołączalność mandatu, poseł, sołtys

Radca prawny, ekspert ds. legislacji Biura Analiz Sejmowych •

Kancelaria Sejmu, Biuro Analiz Sejmowych, Wydział Analiz Prawnych, Zespół Prawa

Prywatnego, WARSZAWA, POLSKA -

joanna.karolczak@sejm.gov.pl • https://orcid.org/0000-0002-5421-4683

\section{Przedmiot opinii}

Przedmiotem opinii jest odpowiedź na pytanie dotyczące "możliwości łączenia mandatu posła $\mathrm{z}$ funkcją inkasenta podatkowego, wykonywanego przez sołtysa. Uprawnienie jest nadane przez radę gminy. Poseł uzyskuje z tego tytułu kwartalne dochody wyliczane procentowo od wysokości wpłat, tzn. w granicach kilkunastu tysięcy złotych rocznie. Czy jest możliwe dalsze wykonywanie funkcji? Czy ten dochód należy zgłosić i w jakiej formie?”.

Opinia została przygotowana $\mathrm{z}$ uwzględnieniem postanowień:

- ustawy z 8 marca 1990 r. o samorządzie gminnym, t.j. Dz.U. 2019, poz. 506, dalej: u.s.gm.,

1 Opinia prawna w sprawie możliwości łączenia mandatu posła z funkcja inkasenta podatkowego sporządzona 4 grudnia 2019 r. na zlecenie posła Klubu Parlamentarnego Prawo i Sprawiedliwość; BAS-WAP 2233/19. 
- ustawy z 29 sierpnia 1997 r. - Ordynacja podatkowa, Dz.U. 2019, poz. 900, ze zm.,

- ustawy z 12 stycznia 1991 r. o podatkach i opłatach lokalnych, t.j. Dz.U. 2019, poz. 1170, ze zm.,

- ustawy z 15 listopada 1984 r. o podatku rolnym, t.j. Dz.U. 2019, poz. 1256, ze $\mathrm{zm}$.,

- ustawy z 30 października 2002 r. o podatku leśnym, t.j. Dz.U. 2019, poz. 888, ze zm.,

- ustawy z 9 maja 1996 r. o wykonywaniu mandatu posła i senatora, t.j. Dz.U. 2019, poz. 1799; dalej: ustawa o wykonywaniu mandatu,

- uchwały nr 26 Prezydium Sejmu z 25 września 2001 r. w sprawie szczegółowych zasad i trybu wypłacania uposażenia poselskiego oraz odprawy parlamentarnej, dalej: uchwała nr 26, według stanu prawnego na dzień 4 grudnia 2019 r.

\section{Uzasadnienie}

Zgodnie z art. 36 ust. 1 u.s.gm. sołtys jest organem wykonawczym w sołectwie, jednostce pomocniczej gminy. Do jego zadań należy wykonywanie uchwał zebrania wiejskiego, a także zadań wynikających z uchwał rad gminy (np. inkasowanie podatków i opłat lokalnych) oraz z przepisów prawa. Sołtysi są często inkasentami podatków rolnego, leśnego i od nieruchomości od osób fizycznych. Zgodnie $\mathrm{z}$ art. 9 Ordynacji podatkowej inkasentem jest osoba fizyczna, osoba prawna lub jednostka organizacyjna niemająca osobowości prawnej, obowiązana do pobrania od podatnika podatku i wpłacenia go we właściwym terminie organowi podatkowemu.

Inkasenci mogą otrzymywać wynagrodzenie prowizyjne za inkaso. Zgodnie bowiem $z$ art. $28 \$ 4$ Ordynacji podatkowej rada gminy, rada powiatu oraz sejmik województwa mogą ustalać wynagrodzenie dla płatników lub inkasentów z tytułu poboru podatków stanowiących dochody, odpowiednio, budżetu gminy, powiatu lub województwa. W myśl art. 6 ust. 12 ustawy o podatkach i opłatach lokalnych rada gminy może zarządzać pobór podatku od nieruchomości od osób fizycznych w drodze inkasa oraz wyznaczać inkasentów i określać wysokość wynagrodzenia za inkaso. Podobnie, zgodnie z art. $6 \mathrm{~b}$ ustawy o podatku rolnym, rada gminy może zarządzać pobór podatku rolnego od osób fizycznych w drodze inkasa oraz określać inkasentów i wysokość wynagrodzenia za inkaso. Analogiczny przepis obowiązuje w ustawie o podatku leśnym - zgodnie $\mathrm{z}$ art. 6 ust. 8 tej ustawy rada gminy, w drodze uchwały, może zarządzić pobór podatku leśnego od osób wymienionych w ust. 2 w drodze inkasa oraz wyznaczyć inkasentów i określić wysokość wynagrodzenia za inkaso.

Powyższe zajęcie należy uznać za „zajęcie dodatkowe” w rozumieniu art. 33 ust. 1 ustawy o wykonywaniu mandatu, wymagające powiadomienia Marszałka 
Sejmu. Jest to także zajęcie zarobkowe. Za zajęcie zarobkowe uznane powinno być bowiem każde zajęcie, które wiąże się z uzyskaniem wynagrodzenia, zapłaty lub też innych korzyści majątkowych i winno eksponować przede wszystkim zarobek lub cel zarobkowy. Termin „zajęcie zarobkowe” powinien być rozumiany szeroko i obejmować wszelkie formy zatrudnienia połączone z uzyskiwaniem dochodów, czyli działalność gospodarczą, stosunek pracy, stosunek służbowy oraz każdy rodzaj umowy cywilnoprawnej ${ }^{2}$. Zajęcie zarobkowe to zajęcie, za które przysługuje wynagrodzenie, a konieczność wypłaty wynagrodzenia może wynikać z przepisów, zawartej umowy lub ogólnie przyjętych zwyczajów3.

Zajęcie polegające na pobieraniu podatków nie koliduje z normami wyrażonym w art. 30 ust. 1 ustawy o wykonywaniu mandatu. Natomiast zajęcie to może naruszać art. 34 ust. 1 ustawy o wykonywaniu mandatu, jeśli jest wykonywane w ramach działalności gospodarczej.

W orzecznictwie Naczelnego Sądu Administracyjnego, wydanym na tle analogicznych przepisów dotyczących radnych, przyjmuje się, że wypłacone zarządzanemu przez radnego podmiotowi gospodarczemu wynagrodzenie $z$ tytułu dokonywania czynności inkasa $\mathrm{w}$ imieniu gminy jest kwalifikowane jako prowadzenie przez radnego działalności z wykorzystaniem mienia komunalnego ${ }^{4}$. Sam fakt pobrania wynagrodzenia ze środków budżetowych gminy jest równoznaczny $\mathrm{z}$ korzystaniem $\mathrm{z}$ mienia gminnego. Uzyskiwanie przez podmiot zarządzany przez radnego wynagrodzenia za wykonane usługi powoduje, że można mówić o „konflikcie interesów” uzasadniających zastosowanie przepisu art. $24 \mathrm{f}$ u.s.gm. ${ }^{5}$. Wynagrodzenie za usługi wykonywane na rzecz gminy (jednostki komunalnej) i wypłacone usługodawcy $\mathrm{z}$ budżetu gminy mieści się w pojęciu prowadzenia działalności gospodarczej na własny rachunek lub wspólnie z innymi osobami $\mathrm{z}$ wykorzystaniem mienia komunalnego. Mienie komunalne obejmuje wszak aktywa, które stanowią nie tylko nieruchomości gruntowe oraz budynki i budowle (majątek trwały), ale także środki pieniężne. Taki sposób rozumienia mienia komunalnego wynika $\mathrm{z}$ art. 43 u.s.gm., zgodnie z którym mieniem komunalnym jest własność i inne prawa majątkowe należące do poszczególnych gmin i ich związków oraz mienie innych gminnych osób prawnych, w tym przedsiębiorstw. Usługodawca realizujący świadczenie w ramach działalności gospodarczej, przez sam fakt pobrania wynagrodzenia ze środków budżetowych - korzysta z mienia

2 Wyrok Wojewódzkiego Sądu Administracyjnego w Poznaniu z 8 października 1015 r., sygn. akt IV SA/Po 467/15, LEX nr 1933084.

3 Wyrok Wojewódzkiego Sądu Administracyjnego w Szczecinie z 25 stycznia 2017 r., sygn. akt II SA/Sz 1395/16, Legalis 1602100.

4 Wyrok Naczelnego Sądu Administracyjnego z 24 listopada 2014 r., sygn. akt II OSK 2892/14, Legalis 1327857.

5 Wyrok Wojewódzkiego Sądu Administracyjnego w Opolu z 14 listopada 2017 r., sygn. akt II SA/Op 490/17, Legalis 1697895. 
gminnego. Jest to zatem działalność prowadzona $\mathrm{z}$ wykorzystaniem mienia komunalnego ${ }^{6}$.

Ponieważ art. 34 ust. 1 ustawy o wykonywaniu mandatu zakazuje prowadzenia działalności gospodarczej z wykorzystaniem mienia komunalnego, to sołtys nie może dokonywać omawianego pobierania podatków w ramach wykonywanej przez siebie działalności gospodarczej.

Jeśli powyższe zajęcie nie jest prowadzone w ramach działalności gospodarczej, to wątpliwość może budzić kwestia wpływu dochodów z tego zajęcia na uposażenie. Zgodnie $\mathrm{z}$ art. 25 ust. 3 ustawy o wykonywaniu mandatu uposażenie nie przysługuje tylko posłowi, który nie korzysta z urlopu bezpłatnego albo prowadzi działalność gospodarczą samodzielnie lub wspólnie z innymi osobami, albo nie zawiesił prawa do emerytury lub renty, $\mathrm{z}$ zastrzeżeniem ust. 3a.

Wypełniając wniosek w sprawie wypłaty uposażenia poselskiego, będący załącznikiem nr 1 do uchwały nr 26 Prezydium Sejmu, poseł oświadcza, że spełnia warunki określone w ustawie o wykonywaniu mandatu posła i senatora do pobierania uposażenia poselskiego bowiem:

- nie pozostaje w stosunku pracy z żadnym pracodawcą,

- pozostaje w stosunku pracy i u każdego pracodawcy korzysta z urlopu bezpłatnego,

- nie prowadzi działalności gospodarczej,

- zawiesił prowadzenie działalności gospodarczej,

- nie pobiera emerytury ani renty,

- zawiesił prawo do emerytury/renty,

- pobiera emeryturę na podstawie:

a) ustawy z 17 grudnia 1998 r. o emeryturach i rentach z Funduszu Ubezpieczeń Społecznych lub ustawy z 20 grudnia 1990 r. o ubezpieczeniu społecznym rolników i ukończył 60 lat (dotyczy kobiet)/65 lat (dotyczy mężczyzn),

a) ustawy z 10 grudnia 1993 r. o zaopatrzeniu emerytalnym żołnierzy zawodowych oraz ich rodzin albo ustawy z 18 lutego 1994 r. o zaopatrzeniu emerytalnym funkcjonariuszy Policji, Agencji Bezpieczeństwa Wewnętrznego, Agencji Wywiadu, Służby Kontrwywiadu Wojskowego, Służby Wywiadu Wojskowego, Centralnego Biura Antykorupcyjnego, Straży Granicznej, Służby Ochrony Państwa, Państwowej Straży Pożarnej, Służby Celno-Skarbowej i Służby Więziennej oraz ich rodzin i emerytura stanowi 75\% podstawy jej wymiaru bez uwzględnienia podwyższenia z tytułu inwalidztwa pozostającego w związku ze służbą.

$6 \quad$ Wyrok Naczelnego Sądu Administracyjnego z 3 sierpnia 2017 r., sygn. akt II OSK 765/17, Legalis 1672981. 
Poseł będący sołtysem, którą to funkcję sprawuje się społecznie ${ }^{7}$, i będący jednocześnie inkasentem, może zgodnie z prawdą złożyć oświadczenie o treści wskazanej w załączniku nr 1 (o ile nie prowadzi działalności gospodarczej).

Dochód z inkasa zostanie uwzględniony w oświadczeniu majątkowym, składanym za dany rok. Omawiane zajęcie winno być także wykazane w Rejestrze Korzyści, bowiem zgodnie $\mathrm{z}$ art. 35a ust. 3 pkt 1 ustawy o wykonywaniu mandatu, do Rejestru należy zgłaszać informacje: $o$ wszystkich stanowiskach $i$ zajęciach wykonywanych zarówno $w$ administracji publicznej, jak i w instytucjach prywatnych, $z$ tytułu których pobiera się wynagrodzenie, oraz pracy zawodowej wykonywanej na własny rachunek.

\section{Podsumowanie}

- Zajęcie wykonywane przez sołtysa jest „zajęciem dodatkowym” w rozumieniu art. 33 ustawy o wykonywaniu mandatu posła i senatora.

- Zajęcie i dochody wynikające $\mathrm{z}$ funkcji inkasenta podatków powinny być wykazane w Rejestrze Korzyści oraz oświadczeniu majątkowym.

- W orzecznictwie sądowoadministracyjnym przyjmuje się, że wypłacone podmiotowi gospodarczemu wynagrodzenie z tytułu dokonywania czynności inkasa w imieniu gminy, jest kwalifikowane jako prowadzenie działalności z wykorzystaniem mienia komunalnego. Gdyby więc sołtys pobierał podatki w ramach prowadzonej przez siebie działalności gospodarczej, musiałby zaprzestać takiej działalności, bowiem art. 34 ust. 1 ustawy o wykonywaniu mandatu zakazuje prowadzenia działalności gospodarczej z wykorzystaniem mienia komunalnego. - W świetle nowego w tej kadencji Sejmu brzmienia załączników do uchwały nr 26 Prezydium Sejmu zajęcie dodatkowe w postaci pobierania podatków przez sołtysa nie ma wpływu na uposażenia poselskie.

7 Zob. wyrok NSA z 3 stycznia 1995 r., sygn. akt II SA 1825/94, LEX nr 10671, oraz z 17 sierpnia 1995 r., sygn. akt II SA 1592/95, LEX nr 24079. Mogą oni natomiast mieć prawo do diety i zwrotu kosztów podróży służbowych (art. 37b u.s.gm.). 